\title{
A világszintű vallásszabadság jogának történetileg egyik legnagyobb fordulópontját adó magyar büntetőper
}

\section{ZALAHEGYI ZOLTÁN}

\begin{abstract}
„Nincs nagyobb [...] lehetetlenség, mint külső erövel kényszeriteni a lelkiismeretet, a lelket, aki felett hatalommal csak a teremtöje bír."
\end{abstract}

A 450 évvel ezelött a lelkiismereti- és vallásszabadság jogát kimondó 1568. januári tordai országgyülés valóban világszínvonalú eredményt hozott, mivel a katolikus, református, evangélikus és az unitárius hit gyakorlását is biztositotta az Erdélyi Fejdelemségben. Ez utóbbi felekezetet vezetö Dávid Ferenc prédikátort azonban a politikai változások következményeként ezen esszé alapján hitújitóként koholt vádak alapján 1579. év húsvétját követöen perbe fogták. A pár évtizede Rómából elökerült iratok alapján az is bizonyitható, hogy istenkáromlás alapján való elitéléséröl koncepciós perben döntöttek.

Jóllehet ez a vallásüldözés rövid távon a protestáns prédikátor halálát okozta a dévai várbörtönében, de végül egy új, magyar alapitású keresztény egyházi formáció, az Unitárius Egyház alapitásához vezetett.

Kulcsszavak: tordai országgyülés (1568), antitrinitáriusok, Unitárius Egyház, koncepciós per

\section{One of the Greatest Turning Points of the Hungarian Criminal Proceedings in the Worldwide Right to Religious Freedom}

450 years ago, the Torda Diet of January 1568, which proclaimed the right to freedom of religion, was indeed an achievement of world-wide importance, as it provided the practice of Catholic, Reformed, Lutheran, and Unitarian faith in the Transylvanian Principality. However, the preacher Ferenc Dávid, who led the latter one, was prosecuted based on false accusations as a neologist, after political changes, as a consequence of a short publication following the Easter of 1579. Based on documents found in Rome a few decades ago, it can also be proved that his conviction on the basis of blasphemy was decided in a conceptual trial.

1 Dávid Ferenc, az Unitárius Egyház alapítója és első püspöke. 
Although in the short run this religious persecution led to the death of the Protestant preacher in the castle prison of Deva, however, eventually it led to the establishment of a new Hungarian-founded Christian church formation called the Unitarian Church.

Keywords: Parliament of Torda (1568), anti-trinitarians. Unitarian Church, Concept Lawsuit

\section{Bevezetés}

440 évvel ezelőtt, 1579. június 1-je és 3-a között a gyulafehérvári fejedelemi palota nagytermében a vallásszabadság jogát rendkívüli módon sértő per zajlott le. Ugyanis addig egy törvényesen müködő egyházat tiltottak be: vezetőjének bebörtönzésén keresztül.

Így több alapvető kérdés merülhet fel bennünk, amelyek közül az első: miért kevéssé ismert a közvélemény számára ez az eljárás, illetve kik voltak ennek az eljárásnak a terheltjei, bírája és kik képviselték a vádat? Másrészt az is fontos kérdés, hogy melyik egyházról volt szó ebben a perben, és ki volt annak vezetője, aki ezt a törvénytelen elítélést elszenvedte? Azonban ennél is fontosabb tisztázni, hogy kik a felelösök abban, hogy az erdélyi vallásszabadság ezen bünetőeljárás kapcsán a mélybe zuhant?

Többek között ezekre a kérdésekre keresem a választ ebben a müben, amely mintegy periratszerűen kronológiai sorrendben kívánja rekonstruálni a per előzményeit és lefolyását, jogászi szemszögből, egy hiteles személyes önéletírás alapján.

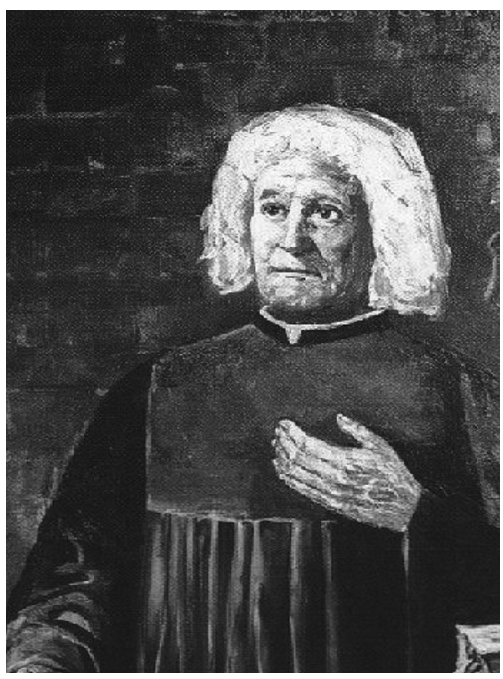

1. ábra: Dávid Ferenc Forrás: NÁNÓ 2014. 


\section{Történelmi háttér}

\section{Az 1500-as évek a kereszténység világszintü megújhodásának kora}

Ahhoz, hogy -annak teljességében - meg tudjuk érteni ezt a büntetőeljárást, rendkívül fontos röviden a 16. századi Erdély politikai, társadalmi és kulturális helyzetét ismerni. Ugyanis a nemrégiben 500 éves évfordulóját ünneplő 1517. október 31-ei, Luther által Wittenbergből elindított reformáció nemcsak a németországi területekre volt hatással, hanem - mint majd látni fogjuk - Erdélyben is új eszméknek és gondolatoknak adott szabad teret. Mindazonáltal az új tanítások, eszmék rendkívül gyorsan (hit)vitákat is szültek a fejedelemségben, amelyek részét képezték a kereszténység világszintủ megújhodásának.

Ezeknek a nézetkülönbségeknek alapvető oka az volt, hogy a vallás és a tudomány, amelyek az emberi tudatlanság eloszlatását tủzték ki célul, látszólag egy egymásnak ellentmondó és összegyeztethetetlen irányba haladtak fejlődésük folyamán. ${ }^{2}$ Tehát a kérdés az volt, hogy a tudomány és a hit mennyiben békíthető ki egymással. E kérdés eldöntésének elsődleges forrása ebben a korban a Biblia volt.

Azonban már itt érdemes megemlítenünk az erdélyi születésủ Dávid Ferenc nevét, aki - a vallás és a tudomány együttműködésének eszményét valóságossá tette, azzal, hogy - a reformáció igazi mintaembere volt, mivel egész életében a reneszánsz igazságeszménye ötvöződik a protestantizmus lelkiismeret-központúságával. ${ }^{3}$

Mindazonáltal ez a "gondolatszabadság” az idegen reformátorokat is idevonzotta egész Európából. Így például Biandratát, Stancarót, Socinust, olasz szabadgondolkodókat és azok követőit, akikről még lesz szó ebben a müben. Azt is be fogom mutatni e tanulmányban, hogy ezekről a hitigazságokról nem ennek a kornak a tudományos szakemberei, hanem a politikai vezetők döntöttek.

\section{A vallásszabadság jogának drasztikus változásai Erdélyben az 1560-70-es években}

Pozitív értelemben ilyen politikai döntéshozó volt a vallászabadság biztosításában a katolikusként született János Zsigmond (1559-1571) erdélyi fejedelem. Ezt a megállapítást az is alátámasztja, hogy 1564-ben az akkor már protestáns fiatal erdélyi fejedelem Dávid Ferencet udvari papjává nevezte ki, aki szorosabb kapcsolatba került a fejedelem udvari orvosával, Blandrata Györggyel, az antitrinitárius eszmék képviselőjével. ${ }^{4}$

Ennek következtében többek között Dávid Ferenc volt az, akinek a tordai országgyủlés 1568 -as vallásbékét hirdető határozata is köszönhetö, ${ }^{5}$ ugyanis az ő nevéhez

2 Moon, Sun Myung (2001): Az Isteni Alapelv kifejtése. Budapest, Szentlélek Társasága a Világ Kereszténységének Egyesítéséért. 8.

3 Szobrot kapott Kolozsváron az unitárius egyház alapitója 2019.

4 Dávid Ferenc.

5 Szobrot kapott Kolozsváron az unitárius egyház alapítója 2019. 
kötődik a vallásszabadság szellemi vívmánya, amelyet a világon először az 1568-as tordai országgyűlés fogalmazott meg úgy, hogy „hitéért senkit üldözni nem lehet”。

Ezt a rendkívül fontos eseményt híres történészünk, Benda Kálmán így értékelte: „A vallásszabadságért vívott harc az emberi jogokért folytatott sok évszázados küzdelem egyik fontos fejezete volt [...] a tordai országgyülés négy vallás - a katolikus, evangélikus, református és unitárius - szabadságát és egyenjogúságát mondotta ki. Tegyük hozzá: elsőnek a világon [...]. Államvallás nincs, az uralkodói hatalom fölötte áll az egyházinak, de nincs joga közöttük bármilyen szempontból különbséget tenni. Nem érvényesül a területi elv sem: bármely városban vagy faluban több felekezet élhet együtt, a földesúr nem avatkozhat be jobbágyai vallási hovatartozásába, a törvény szerint mindenki maga döntheti el, melyik vallást követi."7

E világszintű eredményére emlékezve 2018. február 20-án országgyűlésünk a 450 évvel ezelőtti törvény kihirdetésének napját - január 13-át - a vallásszabadság napjává nyilvánította. ${ }^{8}$ Ezzel kapcsolatban Tőkés reményét fejezte ki, hogy a magyar országgyưlés példáját követve az Európai Parlament is a vallásszabadság napjának nyilvánítja január 13-át, a vallásszabadság tordai kihirdetésének napját. ${ }^{9}$

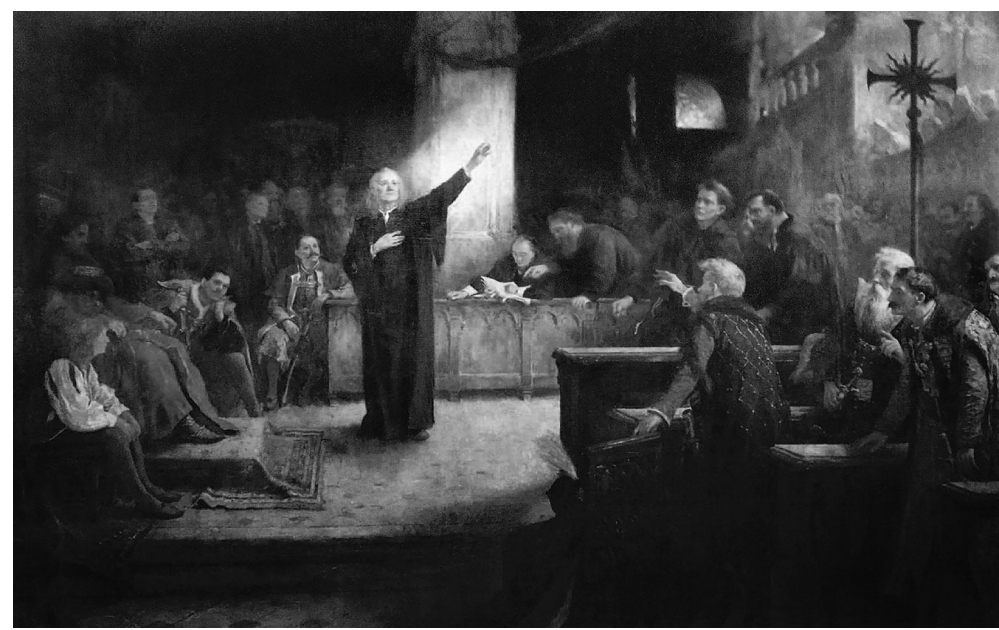

2. ábra: Körösföi-Kriesch Aladár festménye: Az 1568-i tordai országgyülés Forrás: Az 1568-i tordai országgyülés 2018.

6 Részlet az 1568 január 6. és 13. között a tordai országgyülés idevonatkozó határozatának híres passzusából: „Minden helyökön az prédikátorok az evangéliumot prédikálják, hirdessék, ki-ki az ő értelme szerint, és az község, ha venni akarja, jó, ha nem penig senki kénszerítéssel ne kénszerítse [...], de oly prédikátort tarthasson, az kinek tanítása ő nékie tetszik. Ezért penig senki az szuperintendensök közül, se egyebek az prédikátorokat meg ne bánthassa; ne szidalmaztassék senki az religióért senkitől [...], mert a hit Istennek ajándéka." Az 1568-as tordai országgyülés határozatára emlékeztek az erdélyi unitáriusok 2011.

7 BENDA 1994.

8 A vallásszabadság napjává nyilvánitotta az Országgyülés január 13-át 2018.

9 Szobrot kapott Kolozsváron az unitárius egyház alapitója 2019. 
További érdekessége még ennek a korszaknak, hogy ez volt Nyugat-Európában a vallásháborúk időszaka, de Erdély szinte elszigetelt egységként a felekezeti béke földje volt ekkor. Így e vallási türelem kapcsán kimondhatjuk, hogy ez a kis fejedelemség már akkor példát adott a világnak.

Ez a szabadság csak a négy keresztény vallásra, a katolikus, református, evangélikus és unitárius hitre vonatkozott, amely utóbbi lesz majd e mű fó témája.

Horváth Attila jogtörténész, alkotmánybíró e történelmi esemény nagyszerűségét viszont a bevett vallások rendszerének bevezetésében látta. Itt János Zsigmond uralkodásának idejétől már nem számíthatott államvallásnak a katolikus vallás. 1550-ben először az evangélikus, 1564-től a református, 1568-tól pedig az unitárius vallás is „bevett vallás” (recepta religio) lett. Ebből következett, hogy az erdélyi fejedelem patrónusa lett minden egyháznak, amivel európai viszonylatban egyedülálló vallási toleranciát hoztak létre Erdélyben. Lehetővé vált a négy bevett vallás szabad gyakorlása és az áttérés. ${ }^{10}$

Másrészt viszont feszültségek, az új gyülekezeteken belül meglévő ellentmondások jelentek meg, és ezek ingatták meg például az unitárius Dávid Ferenc egyházvezetői helyzetét. Ez készítette elő azt a pert, amely nemcsak tanításait ítélte el, hanem „szinte” életétől is megfosztotta. Ez a mű pedig legfőképp ennek a pernek a tárgyalásáról és értékeléséről fog szólni.

Itt most előzményként csak annyit érdemes megjegyezni, hogy a maga is unitáriussá vált János Zsigmond erdélyi fejedelemsége idején, az 1571. január 6. és 14. között megtartott országgyűlés a kialakult és befogadott vallások védelmében és a kriminális vallások kiűzéséről hozott határozatot. Majd a hitújítással szemben az ezt követő országgyülések további szigorításként innovációellenes határozatokat hoztak, sőt úgynevezett „innovációs perekre” is sor került.

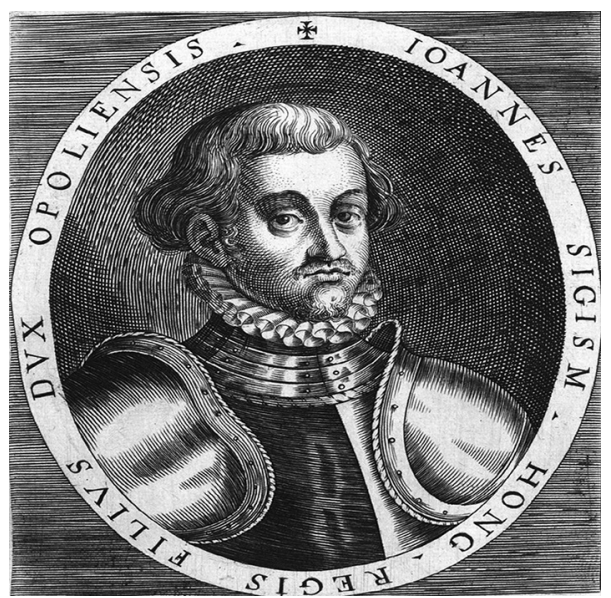

3. ábra: János Zsigmond

Forrás: Az elsö erdélyi fejedelem 2015.

10 HORVÁth 2011. 
Másrészt a 1570-es évek így egyre inkább a katolicizmus újbóli megerősödéséről szóltak. Báthory István trónralépésével azonban a hatalmi helyzet megváltozott, mert az ellenreformáció szelei Erdélybe is eljutottak, majd az 1576-ban fejedelmi székbe került Báthory Kristóf az új irányzat meggyőződéses és aktív támogatója volt. ${ }^{11}$

Ezeknek a feszültségeknek a további eszkalálódását nagymértékben elősegítette az a politikai helyzet, amelybe Erdély a 16. század hetedik évtizedének végén került. Ugyanis a Báthoryak fejedelmi pozícióikat felhasználva az ellenreformáció legnagyobb harcosait, a jezsuitákat hívták udvarukba.

Mindezen összefüggések általánosan jól összegezhetők Kukorelli István alkotmányjogász azon gondolatával, hogy örök vita az állam és az egyház kapcsolata, az ideális modell, amely a történelem, a jog és a politika függvénye. ${ }^{12}$

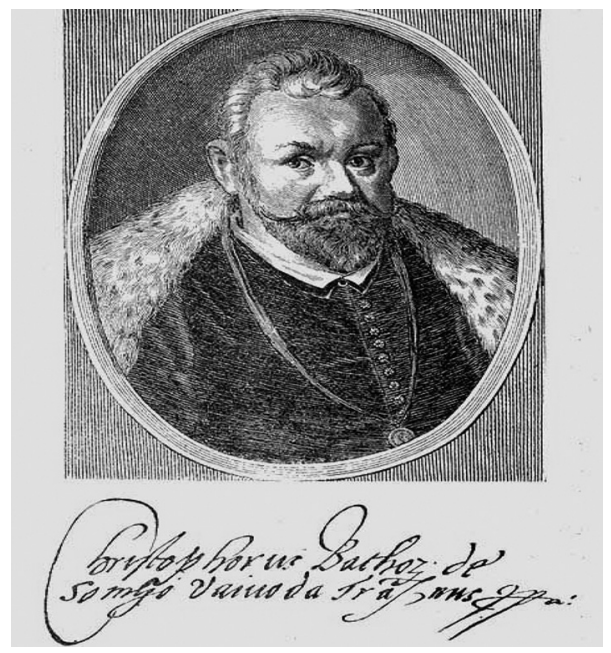

4. ábra: Báthory Kristóf arczképe és aláirása Forrás: Báthory Kristóf arczképe és aláirása

\section{A büntetöper ideológiai és dogmatikai elözményei}

Visszatérve a tanulmányomban feltett legfőbb kérdés megválaszolására, utalnom kell arra, hogy az unitárius hívők sem voltak egységesek. Ugyanis a szentháromságtagadók között heves vita keletkezett Krisztus imádása tekintetében. Két csoport állt szemben egymással, Serveto és Socinus krisztológiáját követő, Krisztus imádását (adoramus) vallók Blandrata vezetésével, valamint a Krisztus imádását (non adoramus) tagadók, élükön Dávid Ferenccel.

11 BODOR 1979, 233.

12 KuKorelli 2014, 133. 


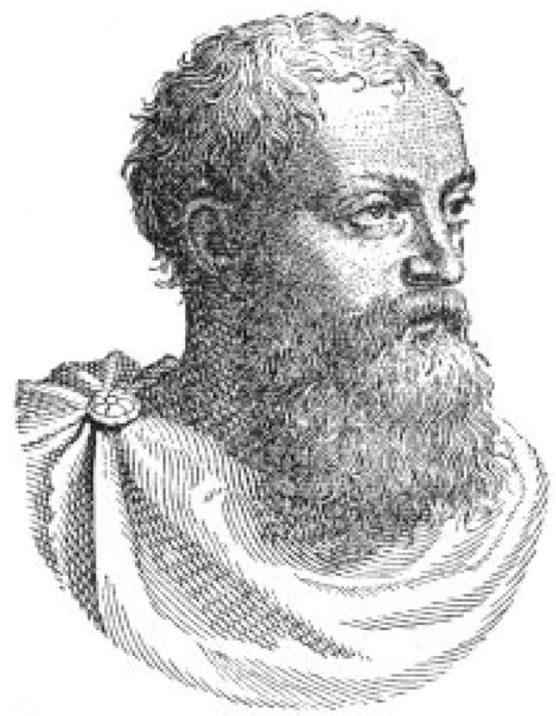

5. ábra: Blandrata György

Forrás: Blandrata György (Wikipédia)

Így Dávid Ferenc - betartva a törvényes kereteket - már 1578 márciusában Tordán zsinatot tartott 322 lelkész részvételével, amely elfogadta az úgynevezett communis profetia elvét, azaz azt, hogy a zsinatilag meg nem állapított hittételekről szabadon lehet vitatkozni. ${ }^{13} \mathrm{~A}$ valóságban ez az elv csak reakció volt az innovációs törvényre, és további lehetőséget biztosított nemcsak a további hitviták, hanem a vallásszabadság számára is.

Ezalatt a másik oldal az 1578 áprilisában Kolozsváron tartott országgyủlésen ismét felújította az innovációs törvényt, sőt külön bizottságot létesített a rendelkezések ellenőrzésére.

A megoldás érdekében Blandrata meghívott egy másik teológus professzort, Faustus Socinust, hogy békés megbeszéléseken tisztázzák a felmerült hitelvi kérdéseket. Socinus 1578 novemberében érkezett Kolozsvárra, és Dávid Ferenc vendége volt 1579 márciusáig, amikor is a magyar prédikátort őrizetbe vétették. Ennek a vendégeskedésnek azonban speciális céljai voltak, ugyanis Socinus Faustust saját költségén Dávid házánál szállásolta el, utasításul adván, hogy minden módot és alkalmat használjon fel a superintendens megtérítésére; egyben vállalkozása sorsáról őt időközönként tudósítsa. ${ }^{14}$ Blandratának e cselekedeteiről a legkülönbözőbb vélemények olvashatók az utókor íróinál, és majdnem valamennyi egyezik abban, hogy a fejedelmi orvos titkos kémnek használta az idegent.

Dávid azonban fenntartotta újszerü hittételeit, így a hitvita úgy folytatódott, hogy 1579. február 28-án a tordai zsinat elutasította a Dávid Ferenc ellen felhozott

13 VÁRI 1940, 240.

14 BorbéLY 1912, 30 . 
innovációs vádat. Ennek következtében Blandrata [hit]újítás címén vádat emelt a fejedelemnél Dávid Ferenc ellen. Ennek eredményeként eltiltották a lelkészi szolgálattól, őrizet alá helyezték és az 1579. április 26-ára meghirdetett tordai országgyúlésre már mint vádlottat idézték meg. ${ }^{15}$

Tehát a per tárgyát látszólag egy doktrinális teológiai vitának tekinthetjük, de kérdés az, hogy ez valóban csak egy ideológiai küzdelem volt, vagy sem? A másik kérdés az, hogy az unitárius gyülekezetvezetők között ilyen erős megosztottság létrehozása kiknek állhatott érdekében, és miért válhatott ez büntetőperré?

\section{Dávid Ferenc „büntetőpere”}

Tényként kell megállapítanunk, hogy a 440 évvel ezelőtti eseményről készült korabeli források rendkívül ellentmondásosak. Az első és legfontosabb a Defensio Francisci Davidis, ebben található az Epistola Fratrum Transilvanorum, az a valószínűleg Trauzner Lukács kolozsvári tanácsi jegyzőtől származó rövid írás, amely Dávid perének lefolyását beszéli el. ${ }^{16} \mathrm{~A}$ másik Faustus Socinus kézirata. Ez tulajdonképpen válasz az előbbire, és szerzője az ellen a vád ellen védekezik, hogy köze lett volna Dávid Ferenc elítéltetéséhez. ${ }^{17}$

Mindezekre figyelemmel erről a perről nagy valószínüséggel a leghitelesebb tájékoztatást és bizonyítékokat Leleszi Jánosnak, a Báthoryak által Erdélybe befogadott jezsuiták vezetőjének a perről levél formában Rómába küldött jelentése adja. E mü címe Documenta Romana Historiae Societatis Jesu in regnis olim corona Hungarica unitis. Ez a Kolozsmonostoron 1579. június 9-én keletkezett irat ${ }^{18}$ más szavakkal az ő önvallomása és önéletírása arról, hogy mit tett ebben a perben, így ez ebben a formában e per elsődleges forrásának tekintendő.

Ezt a megállapítást Bodor András abban is megerősíti, hogy „új fényt vet a per indokaira, és fellebbenti a fátylat a kulisszák mögötti tárgyalásokról", ugyanis a bíró pozíciójában lévő fejedelemnek nemcsak „az a szándéka, miként lehetne a reformáció legszélsőségesebb, ezért a legveszedelmesebb ágát visszaszorítani", hanem az is, hogy „a szemben álló két fél lényegében eszköz, akik elfogultságukban észre sem veszik, hogy bizonyos célok érdekében tudatosan irányított bábok csupán". ${ }^{19}$

Magáról a perről pedig ugyanezen szerző a következő összegzést adja: „a gyulafehérvári országgyủlés e jelentés tükrében már nem hitvita, hanem életbevágó, előre megrendezett politikai per, amelyen már a tárgyalás előtt megvan a döntés, és a vádlott kivételével talán mindenki csupán előre betanult szerepét játssza." ${ }^{20}$ Tehát azt mondhatjuk, a mai jogi fogalmakkal élve, hogy ez egy koncepciós per volt, amelynek

15 BODOR 1979, 233.

16 Könyvszemle 1978.

17 Bodor 1968, 1209.

18 Tartalmában majd látni fogjuk, nem véletlenül ez a leghitelesebb mű erről a perről. Rómából csak 1965-ben került elő a II. 353-357. jelzéssel. (A szerző megjegyzése.)

19 Bodor 1968, 1211.

20 BODOR 1968, 1211. 
lényegét a jogi szakirodalom így fogalmazza: „a vád olyan politikai értékelésen alapul, amely a perben nem tehető vitássá". ${ }^{21}$

Ezek alapján nem véletlen, hogy az idén pont 440 évvel ezelőtti per valódi adataihoz alig fél évszázada lehet nyilvános hozzáférése a nagyközönségnek, más szavakkal a per jegyzőkönyvét és annak igaz hátterét több száz évre titkosította a Vatikán. Mindezek fényében érdemes áttekinteni a per egyes szakaszait, hogy azok mennyiben támasztják alá a fenti állításokat.

\section{A „per” elökészületei}

Ezen Leleszi jelentésnek 1. pontja szerint már a tordai rendi országgyúlésen, az 1579. év húsvét utáni első és második hetében megkezdődtek a per előkészületei. A jezsuita szerzetes már a perelőkészítési szakaszban előre meghatározott célként, minden kétséget kizáróan Dávid Ferenc prédikátori bűnösségét akarta tűzön-vízen át bebizonyítani.

Ezt bizonyítja, hogy jelentésének első soraiban leírja, hogy a „fejedelem [...] az öszszes világi és egyházi bírák tanácsának kikérésével intézkedjék ez ügyben, s ez alatt Dávid Ferencet őrizet alatt tartsák.”22 Erre azért volt szükség, mert a köznép és a városi plebejus réteg között voltak követői a kiemelkedő magyar reformátornak, de még az erdélyi nemesség körében is.

Így a jezsuita pap igazi ellenreformátorként először arról próbálta meggyőzni a fejedelmet, hogy az unitarizmus létezésének jogalapját is szüntesse meg, mert voltak, akik „törvénybe akarták iktatni az ország nevében az eretnekség elfogadását, de intézkedtem, hogy ha csak egyetlen katolikus lenne is jelen, az azonnal tiltakozzék". ${ }^{23}$

Másrészt Dávid ellen voltak az erdélyi állam jelentős részét kitevő erdélyi szászok, akik lutheránusokként is erősen haragudtak Dávid Ferencre. Ennélfogva mihelyt egyetlen katolikus tiltakozni kezdett, azok követték őket.

Emiatt az országgyűlésen a magyar reformátor érdekében a követői semmit sem tudtak elérni, így a terhelt idézése és háziőrizetbe vétele az alábbiak szerint történt: „Ennélfogva az a határozat hozatott, mely szerint június elsejére hívjanak össze országgyűlést Gyulafehérvárra, arra Dávid Ferencet tizenkét papjával együtt idézzék meg; [...] Dávidot húsz darabontra bízták, azzal a meghagyással, hogy mindenkit tartsanak távol a vele való találkozástól. Így erős őrizet alatt Kolozsvárra küldték saját házába."24

Leleszi jelentésének 2. és 3. pontja világossá teszi, hogy a fejedelem - mind elméleti és teológiai, mind gyakorlati síkon - csak saját hatalmának megerősítése végett erőltette ezt a „pert”, tette pedig ezt oly módon, hogy az külsőleg csak doktrinális vitának tűnjön és ne (egyház)politikai küzdelemnek. Leleszi János azt is leírja, hogy

21 LAMM 2009, 393-394.

22 Bodor 1968, 1212.

23 BODOR 1968, 1212.

24 BODOR 1968, 1212. 
amikor ő még Tordán volt: „Nagyságos Fejedelem magához hívatott és mintegy hat órát vagy még ennél is több ideig mindenről elbeszélgettünk egymással. Átadta nekem D. Ferenc téziseit azzal, hogy azokat a Szentírásból vett helyekkel röviden cáfoljam meg." ${ }^{25}$

Koncepciós perről volt szó a bírói pozícióban lévő fejedelem érdeke miatt is. A fö (hit)elvi kérdés látszólag ez volt: „Ki kételkedhetnék abban, hogy Krisztust imádni kell? Ki ne tudná, hogy ő az örök élet adója?” Ezzel szemben a fejedelem számára a valóságos kérdés ez: „[...] ha most támadna egy megátalkodott rebellis, aki azt kezdené állítani, hogy Nagyságodnak engedelmeskedni nem kell, és elpártolásra hívná fel az országot?"26 - amely kérdéssel kitűnően érvelt a jezsuita hitharcos.

A jelentés azt is hủen bizonyítja, hogy a fejedelem ezt a célt, vagyis az engedelmességet a fejedelemnek az ellenreformációt támogató törekvéseivel kívánta elérni. Példa rá a kolozsvári Farkas utcai templom katolikusoknak való visszaadása - ami ezen vallási közösség központi vagyonát képezte -, ez az alábbiak szerint történt: „A tanács a templomot még aznap át is adta. Mindent megtisztítottunk, időleges használatra faoltárt építettünk, a szobrokat és a festményeket, amelyekről valamiképpen megtudtuk, hogy a polgároknál vannak, bírói felhatalmazással felhajhásztuk és elhoztuk. [...] A kelyhet és vele együtt a legértékesebb papi ornátusokat a Nagyságos Fejedelem adta." ${ }^{27} \mathrm{Ez}$ a törvénytelen esemény 1579-ben a húsvét utáni harmadik vasárnapon befejeződött, ami ugyancsak a per koncepciós voltát mutatja. Ugyanis nemhogy az ítélet, hanem még a tárgyalás előtt - mai jogi szakkifejezésekkel élve - az akkori államhatalom törvénytelen elkobzást és kisajátítást hajtott végre az unitárius gyülekezet kárára.

A jelentés 4. pontja is híven tükrözi a per fent említett jellegét, hiszen ebben a perben: „Fejedelem írásba foglalva elküldte hozzám a per egész sorrendjét, éppen ezt a lapot, melyet ideiktatva láthattok; ebből világosan kivehető a per egész indoklása és lefolytatása." ${ }^{28} \mathrm{Ez}$ megint csak kimeríti a jogi terminológia koncepciósperfogalmát, mert ez a per is csak külsőségeiben tekinthető büntetőeljárásnak, ténylegesen a jog mellőzésével tisztán politikai célokat szolgál, ami a perbeli érvelésen is jól látható. ${ }^{29}$

Ezt a jelentés 5. pontja is alátámasztja. Először is azzal, hogy a fejedelem meghagyása alapján meghívottaknak június elsején reggel hét órakor kellett összegyủlniük a fejedelem nagytermében, Gyulafehérvárott. Nem véletlenül nem Kolozsvár a helyszín, ahol Dávid Ferenc tevékenykedett és lakott híveivel együtt, hanem az elfogult bírói pozícióban lévő fejedelemi székhely. Másrészt a fejedelem Dávid Ferencet azon a jogcímen idézi meg, hogy az egyházközségek hitújítónak mondják. Harmadrészt a per koncepciós voltát az előre előkészített bizonyítási eljárás is alátámasztja. A jogi szakirodalom szerint: „Olyan büntetőper (vagy annak külsőségeit követő állami ak-

25 Bodor 1968, 1213.

26 BODOR 1968, 1213.

27 Bodor 1968, 1213.

28 Bodor 1968, 1214.

29 LAMM 2009, 393-394. 
tus), amely a vádhatóság és a bíróság jogellenes együttműködésével koholt, hamis vagy hamisított bizonyítékok (bizonyítás, bizonyítás tárgya) alapján állapítja meg súlyos politikai (államellenes) bűncselekmény elkövetését a vádlott (terhelt) terhére." ${ }^{30}$

A két lehetséges opcióra (igen/nem), illetve tagadó válaszokra is előre felkészült a fejedelem, ugyanis a jelentés 4. pontja alapján: „Ha D. Ferenc e tényt tagadná, akkor tanúk és iratok által rá fogják ezt bizonyítani." ${ }^{31}$ Ezek a személyek pedig azok közül kerültek ki, akik megosztott hívei voltak az unitarizmusnak. Az 5. pont szerint: „Ha azonban azt mondaná, hogy ez a valóság, és makacsul igyekezne ezt megvédeni, akkor Blandrata doktor, annak az egyháznak a seniora, amelynek D. Ferenc a superintendense volt, és e felekezetnek többi papja, valamint a többi erdélyi meg magyarországi egyházközség be fogja bizonyítani az írások alapján és élőszóban, hogy Dávid Ferencnek ez a hittétele nemcsak új, hanem istenkáromló is."32

Az ítélet jogi alátámasztására ${ }^{33}$ előre felkészülve, a 6. pontban azt is kifejti a jezsuita szerzetes, hogy: „Minthogy azonban ebben a tárgyban már volt egyszer kiadva nyilvános tiltó rendelet, nehogy valaki a vallás dolgában az egyházba valami újat bevezessen, ezért e kérdésben utólagos disputára szükség nincsen, hanem mindenekelőtt annak a vallásnak tudorai fejtik ki, hogyan kell vélekedni D. Ferencről." ${ }^{34}$

Önmagában e néhány pontnak bemutatása is jelzi, hogy mennyire előre megtervezett tárgyaláselőkészítés és bizonyításfelvétel alapján történt az egész eljárás, melyet így a koncepciós per - előkészítése - tipikus esetének tekinthetünk, mely megállapítást a tárgyalási szakasz „hiteles jegyzőkönyve” is az alábbiak szerint megerősíti.

\section{A „tárgyalás”}

A tárgyalás valódi jellegét közvetetten az is mutatja, hogy bevezették Dávid Ferencet, mocskosan, porlepetten, remegve, ${ }^{35}$ tehát nagy valószínűséggel fizikai erőszakot is alkalmazhattak az unitárius prédikátorral szemben.

A vád tárgya - a fentiekben már ismertetett - látszólag egy fontos teológiai kérdés megvitatása körül zajlott, aminek lényege és lefolyása a következőkben foglalható össze a jelentés szerint: A fejedelem válaszadásra szólította fel, vajon ő-e a szerzője azoknak az újításoknak, amelyeket mindenfelé terjesztenek? Nyomban ezután Blandrata Dávid írásaiból és mondásaiból előadta az istenkáromlásokat, amelyeknek a lényege a következő: Krisztust semmiképpen sem kell imádni, senkinek semmilyen segítséget nyújtani nem képes stb. Amikor azt kérdezték tőle, vajon hirdette-e ezeket, először azt felelte, hogy ő Tordán ezeket nem prédikálta. Mégis később, amikor a sok kérdezéssel ezt rábizonyították, beismerte, hogy ez volt az ő véleménye, ezt tanította

30 LAMM 2009, 393-394.

31 BODOR 1968, 1214.

32 BODOR 1968, 1214.

33 Ezzel elég pontos definícióját adta meg a jezsuita pap az innovációnak, azaz a hitújításnak.

(A szerző megjegyzése.)

34. BODOR 1968, 1214.

35 BODOR 1968, 1215. 
és kész megvédeni. Mihelyt azonban a fejedelem újítással kezdte vádolni ${ }^{36}$ megváltozott Dávid Ferenc magatartása, mert itt már végképp nyilvánvaló volt számára az eljárás végkimenetele. Az egyházalapító ebben is a jézusi példát mutatta, és a mártíromságot is vállalta, mert ez volt az igazság melletti megmaradás egyedül igaz járható útja. $^{37}$

Ezt követően a vádlott kérésére a tárgyalást elnapolták az alábbiak szerint: „könyörögve még egy nap engedélyezését kérte számára, hogy pontosabban válaszolhasson és felkészüljön annak bizonyítására, hogy ő mindig, kezdettől fogva, ugyanazt tanította." ${ }^{38}$ Másrészt ez azt is bizonyítja, hogy Dávid Ferenc a vádat pontosan csak a tárgyaláson ismerhette meg. „Ezt az elnapolást a fejedelem csak azért engedélyezte, nehogy azt mondhassa, nem az igazság törvényével, hanem erőszakkal ítélték el. Így aznap az országgyủlés véget ért."39

A következő nap, 1579. június 2-án, reggel hét órakor megjelent D. Ferenc, és azt akarta bebizonyítani, ő mindig azt tanította, hogy Krisztust nem kell imádni, és tőle semmi segítséget nem kell kérni. És azt bizonygatta műveiből, hogy nincs semmi más, csak az Atyaisten, az egyetlen és imádandó Isten, ${ }^{40}$ amely gondolat később az unitarizmus alapjává lett.

A vád úgy folytatódott, hogy „Blandrata ezzel szemben társaival együtt azt állította, hogy a vita nem arról folyik, vajon az Atyát imádni kell-e, hanem arról, vajon tanította-e, hogy Krisztust nem kell imádni." ${ }^{\prime 1}$ Ez azt mutatja, hogy a korábban azonos hitelven lévő olasz prédikátor most már kvázi vádlóként lép fel saját gyülekezetvezetője ellen.

Így a bizonyítási eljárás a tanúk szóbeli megnyilatkozásai alapján a következőképpen történt az ellenreformátor leírása szerint: „Miután a teremből kivezették, a Fejedelem mindenkit felkért, hogy mondjon véleményt e három kérdésben: Elöször: magukévá tették-e valaha is D. Ferencnek ezt a nézetét és tanát? Másodszor: vajon ez a tan új-e? Harmadszor: vajon istenkáromlás-e?"42

Elsőnek Blandrata és hívei fejtették ki véleményüket külön-külön. Mindannyian azt bizonygatták, hogy ők ebben a kérdésben nem értettek egyet D. Ferenccel. Továbbá azt állították, hogy nem is hallottak róla, és hogy ez az egész keresztény vallást felforgatja ${ }^{43}$ Itt két problémát kell tisztázni. Elsősorban azt, hogy Blandrata hogyan állíthatta ezt teológiai gyakorlattal? Másrészt pedig ugyanezen személy a fentiek szerint egyszerre (hamis) tanú és vádló is. Socinus Faustus 1595-ben keletkezett De Jesu Christi invocatione disputacio című művéből kiderül, hogy Blandrata

36 BODOR 1968, 1215.

37 Szobrot kapott Kolozsváron az unitárius egyház alapitója 2019.

38 Bodor 1968, 1215.

39 BODOR 1968, 1215.

40 Bodor 1968, 1215.

41 Bodor 1968, 1215.

42 Bodor 1968, 1216.

43 Bodor 1968, 1215. 
szerint kötelező Krisztus imádása. Ezért Socinust nem léptették fel a gyulafehérvári perben, hanem Blandrata volt a fővádló. ${ }^{44}$

Ezt követően a megrendezett bizonyítási eljárás részeként, tanúként a következő vallomást tette a hiteles leírások szerint: „Először a doktor állt fel, és ilyenféle esküt tett: Én, Blandrata György, vallomást teszek a mindenható Isten és az ő fia, az Úr Jézus Krisztus előtt, a szent angyalok és Isten választottjai előtt, hogy semmiben sem voltam Dávid Ferencnek ezen a véleményén, sem részese, sem tudója annak nem voltam, és állítom, hogy ez új, és ezenfelül Istennek és az ő fiának iszonyatos káromlása." ${ }^{45}$

A tanúk második csoportjaként „a kálvinista és a lutheránus papok következtek, akik ugyanazt hajtogatták, amit Blandrata”.46

Végül mintegy a tanúk harmadik és negyedik vonalaként: „Azután a D. Ferenc pártjához tartozó nemesekre került a sor, ezeknek állhatatlansága és pálfordulása egyenesen elképesztőnek látszott. Először ugyanis mesterük, D. Ferenc ellenében azt állították, hogy ők sohasem hallották tőle ezt a tanítást. Kezdetben nem merték istenkáromlásnak nevezni, azután mégis, ha későn is, annak mondották. Negyediknek az ország elökelőire került sor, közülük azok, akik a Fejedelemtől balra ültek, mind elítélték. Ezután mi következtünk. Azok, akik az én két oldalomon ültek, szintén elítélték." ${ }^{47}$

Végül a jezsuita szerzetes leírása alapján a fejedelem - a semlegesnek látszó bíró - véleménye, amely megegyezett az enyémmel, ez volt: „hiszünk az Atyaistenben, Jézus Krisztusban, az ő Fiában és a Szentlélekben, a lényegében egy, személyében három Istenben. Ennélfogva Dávid Ferencnek ezt a nézetét mi is újnak és istenkáromlónak tartjuk." 48

Így összegezve az elítélés jogi alapja az volt, hogy hitújítóként és így istenkáromlás bűntettének elkövetéséért ítélték el Dávid Ferencet.

\section{Az istenkáromlás büncselekménye és maga az itélet}

Először nézzük meg most ennek a büncselekménynek a - történeti - hátterét.

A káromkodás csak az ország három részre szakadása körüli időszakban terjedt el. Mezey Barna kitűnő jogtörténészünk azt is kifejti ezzel kapcsolatban, hogy „a mohácsi vész előtti időszakban [...] Törvényi rendelkezés nem született, a peranyagokban e büncselekmény nem bukkan fel. [...] Az első rendelkezést az 1566:23. törvénycikkben leljük (néhány esztendőnyire tehát a Habsburg Magyarország diétájának végzésétől), e rövid articulus azonban csupán a lélek és az Isten teremtményeinek szidalmazásáról szól." ${ }^{9}$

\footnotetext{
44 BOTÁr 1955, 338.

45 BOD 1979, 781.

46 Bodor 1968, 1216.

47 Bodor 1968, 1216.

48 Bodor 1968, 1216.

49 Mezey 1986, 56-57.
} 
Másrészt a fentebb leírt dolgozatom egészét alátámasztja a következő idézet ugyanattól a szerzőtől: „Az erdélyi fejedelemség országyülései jóval bővebben foglalkoztak e tényállással. Legkevesebb kilenc dieta rendelkezett a káromkodás bűncselekményéről."50 Ezt később a Rákóczi-szabadságharc joganyaga is beillesztette törvénykönyveibe.

Ilyen előzmények után vezették be Dávid Ferencet, hogy meghallgassa az ítéletet, amelyet Kendi Sándor kancellár az országgyűlés nevében hirdetett ki: „A Nagyságos fejedelem az egész ügyet megértette, hogy te agyad tanácsát követve, az egyház beleegyezése nélkül ezen istentagadó, kárhozatos és hallatlan káromlásra vetemedtél $\mathrm{s}$ az ország törvényei ellenére újításokat tettél; ő Nagysága azért téged érdemed szerint megbüntetve például állít, hogy az másokat is hasonló őrült újításoktól visszarettentsen. További határozatig pedig őrizet alatt fogsz tartatni." ${ }^{51}$

Így tehát ettől a pillanattól kezdve az unitárius prédikátor jogi értelemben a fejedelem foglyává vált.

Ezt követően a tárgyalást másodszor is elnapolták, ugyanis azt kezdték kérni, hogy válaszolás végett biztosítsanak számára még egy napot. Ezt vonakodás nélkül engedélyezték..$^{52}$

A harmadik nap „miután összegyültünk, az ügy hamar véget ért [...]. Ugyanis mindannyian takarodót fújtak, egyetlenegy ember, D. Ferenc vejének a kivételével, akit, minthogy akkor makacsabbul kiállott, bilincsbe is vertek. Igaz, később ő is elpártolt D. Ferenctől." ${ }^{33}$ Így hát az utolsó tanítványa is elpártolt a magyar refomátortól és egyedül maradt, akárcsak Péter, amikor megtagadta Jézust.

\section{Az elítélt további sorsa és perének utóhatásai}

Ennek a műnek összefoglalásaként, végül leírom mi történt Dávid Ferenccel és azt, hogy perének milyen utóhatásai voltak.

Egyrészt a szakirodalomban sincs megegyezés a halál időpontjában, de az biztosra vehető, hogy a dévai vár börtönében, a fejedelem foglyaként halt meg. A leginkább valószínű az 1579. november 15 - ei ${ }^{54}$ dátum erre vonatkozóan. Másrészről az sem tisztázott, hogy miben hunyt el Dávid Ferenc (1520-1579), de az bizonyos, hogy már elörehaladott kora miatt is beteg volt, ugyanis már „az eljárás közben kór gyötré. Fel van jegyezve, hogy kólikája ez idétt nagy fájdalommal kínzá. Talán a közeli halál sejtelme is segített edzeni lelkierejét, ha már a testi erő kezdi elhagyni." 55

Mindezek ellenére kolozsvári hívei kísérletet tettek a fejedelemnél szabadon engedésére a Kolozsvár Városi Jegyzőkönyv alapján, eredménytelenül. ${ }^{56} \mathrm{Ez}$ is azt mu-

50 MeZEy 1986, 57.

51 ERDŐ 1988, 224.

52 BODOR 1968, 1216.

53 BODOR 1968, 1216.

54 ERDŐ 1988, 224.

55 BORBÉLY 1912, 30.

56 XLI. Szemelvények Kolozsvár város 1579. évi közgyűlései jegyzőönyvéből 1879, 106. 
tatja, a fó cél, az unitárius vallási felekezet ennek ellenére sem szünt meg, hanem jelen korunkban is aktívan létező bevett egyház ${ }^{57}$ hazánkban. Így tehát Dávid Ferenc neve és egyháza örökre bevésődött a világtörténelembe, a vádlók neve pedig feledésbe merült. Másrészt ezen ügy végkifejletét tekintve alátámasztja azt a gondolatot, hogy a „vallásszabadság minden szabadság alapja”,58 és ezért aratott hosszú távon győzelemet a Dávid Ferenc vezette unitarianizmus, amely megállapításomat jelen korunk több eseménye is alátámasztja.

Ezt egyrészt a jelenkor azon tisztelgése is jól kifejezi, miszerint 2018. november 12-én a Magyar Nemzeti Bank „450 éves az unitárius egyház” emlékérmét bocsátott ki ${ }^{59}$ az egyetlen magyar alapítású egyház 450 éves fennállásának alkalmából.

Másrészt az is, hogy 2019. augusztus 17-én felavatták az unitárius egyház alapítójának egész alakos szobrát Kolozsváron.

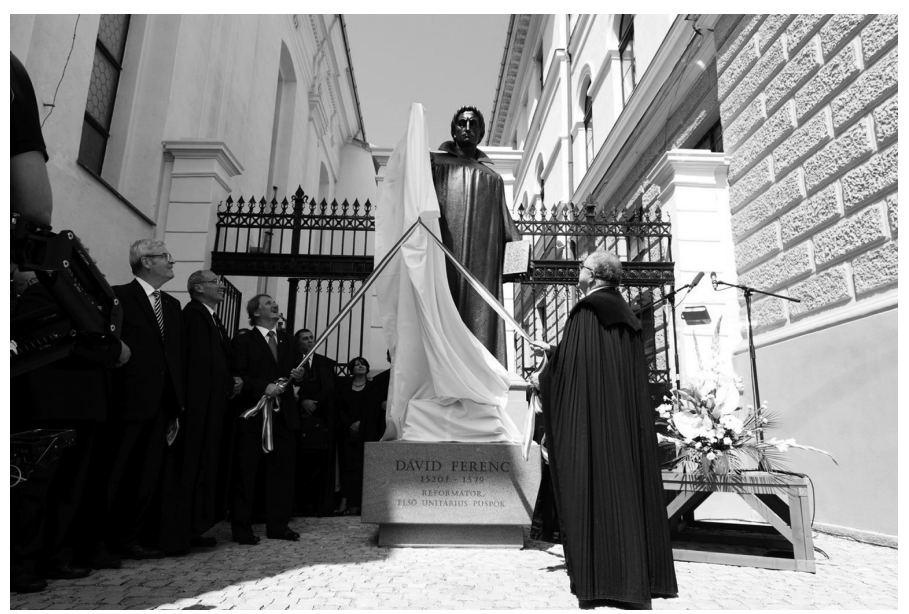

6. ábra: Dávid Ferenc szobrának avatása Kolozsváron 2019. augusztus 17-én Forrás: Szobrot kapott Kolozsváron az unitárius egyház alapitója 2019.

Az ott elhangzott beszédek közül kitűnő zárógondolatul szolgál számunkra az, amit Gergely Zoltán szobrászművész alkotásáról mondott: a szobor nem Dávid Ferencet ábrázolja, hanem azt, amit 2019-ben szellemiségéről, életútjáról és a ránk hagyott eszmei örökségéről gondolunk. ${ }^{60} \mathrm{Ez}$ az örökérvényüség az, amely publikációm megírásának célját és címválasztását is alátámasztja, mert ténylegesen ez volt a világszintü vallásszabadság jogának történetileg egyik legnagyobb fordulópontját adó magyar büntetőper.

57 2011. évi CCVI. törvény Melléklet: A bevett egyházak: 12. Magyar Unitárius Egyház Magyarországi Egyházkerülete (Magyarországi Unitárius Egyház).

58 Moon 2010, 191.

59 Emlékérme-kibocsátás 2018.

60 Szobrot kapott Kolozsváron az unitárius egyház alapitója 2019. 


\section{Felhasznált irodalom}

BENDA Kálmán (1994): Az 1568. évi tordai országgyülés és az erdélyi vallásszabadság. Elhangzott 1993. március 20-án Tordán, az erdélyi vallásszabadságot kinyilvánító 1568-as tordai országgyűlés 425. évfordulója alkalmával rendezett ünnepség tudományos ülésszakán. Erdélyi Múzeum, 56. évf. 3-4. füzet.

BoD Péter (1979): Tragoedia Francisci Davidis. Korunk, 38. évf. 10. sz. 777-782.

Bodor András (1968): Újabb adatok egy négyszázéves perről. Korunk, 27. évf. 8. sz. 1208-1216.

Bodor András (1979): Dávid Ferenc emlékezete. Keresztény Magvetö, 85. évf. 4. sz. 232-241.

BORBÉLy István (1912): Dávid Ferenc és kora. Keresztény Magvetö, 47. évf. 1. füz. 20-35.

BотÁR Imre (1955): Újabb adatok Dávid Ferenc életéhez. Irodalomtörténeti Közlemények, 59. évf. 3. sz. 337-338.

ERDő János (1988): Mikor halt meg Dávid Ferenc? Keresztény Magvető, 94. évf. 4. sz. 223-230.

HoRvÁth Attila (2011): A vallásszabadság és az egyházjog története Magyarországon az államalapítástól a II. világháborúig. Hét Társ, 10. évf. 3-4. sz. 12-20. Elérhető: http://real.mtak. hu/34851/7/vallasszabadsag_es_egyhazjog_tortenete_magyarorszagon.pdf (2019.10. 01.)

Könyvszemle (1978). Keresztény Magvetö, 84. évf. 1. sz. 78. Elérhető: http://epa.oszk. hu/02100/02190/00131/pdf/KM_1984_01_050.pdf (2019.02.15.)

KuKorelli István (2014): Magyarországot saját alkotmánya nélkül kormányozni nem lehet. A közjogász almanachja. Budapest, Gabriel-Méry Ratio Kiadó. 133.

LAMм Vanda szerk. (2009): Jogi lexikon. Budapest, Complex. 393-394.

Mezey Barna (1986): A káromkodás (blaszfémia) a XVII-XVIII. század büntető jogszabályaiban. Jogtörténeti Szemle, 1. évf. 1. sz. 56-65.

Moon, Sun Myung (2001): Az Isteni Alapelv kifejtése. Budapest, Szentlélek Társasága a Világ Kereszténységének Egyesítéséért.

Moon, Sun Myung (2010): Békeszerető világpolgárként, Budapest, Egyesítő Egyház.

VÁRI Albert (1940): Dávid Ferenc nyomain. Keresztény Magvetö, 72. évf. 6. füz. 232-241.

XLI. Szemelvények Kolozsvár város 1579. évi közgyủlései jegyzőkönyvéből. Dávid Ferenc letartóztatására vonatkozó határozatok Kolozsvár 1579-ki jegyzőkönyvéből (1879). Keresztény Magvető, 14. évf. 2. füz. 106.

\section{Jogi forrás}

2011. évi CCVI. törvény a lelkiismereti és vallásszabadság jogáról, valamint az egyházak, vallásfelekezetek és vallási közösségek jogállásáról

\section{Internetes források}

Az 1568-i tordai országgyülés (2018). Elérhető: https://e-nepujsag.ro/articles/az-1568-i-tordaiorsz\%C3\%A1ggy\%C5\%B11\%C3\%A9s (2019. 02. 05.)

Az 1568-as tordai országgyülés határozatára emlékeztek az erdélyi unitáriusok (2011). Elérhető: http://tortenelemportal.hu/2011/01/az-1568-as-tordai-orszaggyules-hatarozatara-emlekeztekaz-erdelyi-unitariusok/ (2019.02.01.)

BáthoryKristófarczképeés aláirása. Elérhető: http://keptar.oszk.hu/html/kepoldal/index.phtml?id $=005732(2019.02 .05$. $)$ 
A világszintủ vallásszabadság jogának történetileg egyik legnagyobb fordulópontját adó...

Blandrata György. (Wikipedia) Elérhető: https://la.wikipedia.org/wiki/Georgius_Blandrata\#/media/Fasciculus:Giorgio_Biandrata.jpg (2019.02.05.)

Dávid Ferenc. Elérhető: www.arcanum.hu/en/online-kiadvanyok/Lexikonok-magyar-eletrajzi-lexikon-7428D/d-750BB/david-ferenc-75124/ (2019. 02.15.)

Az első erdélyi fejedelem (2015). Elérhető: https://erdelyinaplo.ro/szabadido/az-elso-erdelyi-fejedelem/print (2019. 02. 05.)

Emlékérme-kibocsátás az egyetlen magyar alapítású egyház tiszteletére, 450 éves az unitárius egyház. (2018). Elérhető: www.mnb.hu/bankjegy-es-erme/emlekermek/2018/emlekerme-kibocsatasaz-egyetlen-magyar-alapitasu-egyhaz-tiszteletere-450-eves-az-unitarius-egyhaz (2019. 02. 15.)

NÁNó Csaba (2014): Dávid Ferenc szabadsága. Elérhető: https://erdelyinaplo.ro/szabadido/davidferenc-szabadsaga\# (2019.02.05.)

Szobrot kapott Kolozsváron az unitárius egyház alapitója (2019). Elérhető: https://hirado.hu/kulfold/kulpolitika/cikk/2019/08/17/szobrot-kapott-kolozsvaron-az-unitarius-egyhaz-alapito/ (2019. 10. 01.)

A vallásszabadság napjává nyilvánította az Országgyülés január 13-át (2018). Elérhető: www.parlament.hu/-/a-vallasszabadsag-napjava-nyilvanitotta-az-orszaggyules-januar-13-at (2018. 11. 30.) 